DOI: https://doi.org/10.32839/2304-5809/2021-3-91-62

удК 343.2

Мисливий В.А., Огіевич С.М.

Національний технічний університет України «Київський політехнічний інститут імені Ігоря Сікорського»

\title{
ЗЛОЧИННИЙ НАМІР ЯК КАТЕГОРІЯ У КРИМІНАЛЬНОМУ ПРАВІ УКРАЇНИ
}

\begin{abstract}
Анотація. Дана стаття присвячена дослідженню поняття «намір» з огляду на необхідність його вживання в новій редакції Кримінального кодексу України. У ході роботи виявлено ряд проблем та неврегульованих питань стосовно теми дослідження. Зокрема було з'ясовано, що при неодноразовому використанні в Кодексі поняття «намір», його тлумачення законодавцем не надається. На підставі цього нами було проаналізовано значення поняття «намір» шляхом фрілологічного дослідження: з'ясовано особливості тлумачення терміну та його етимологічне значення. Оскільки намір безпосередньо формуеться у свідомості людини та залежить від її волевиявлення необхідним став розгляд категорії «намір» на основі психологічних праць та досліджень. Таким чином було віднесено «намір» до одного з етапів складного вольового акту та визначено його як обов'язковий елемент будь-якої форми людської діяльності, виникнення якого може бути раптовим та зумовлюеться життевими обставинами. У ході роботи було зауважено, що складність визначення та законодавчого закріплення терміну «намір» зумовлені його безпосереднім відношенням до психологічних процесів життедіяльності людини. Проте, важливе значення даного терміну пояснюеться наявністю ряду питань, зокрема що стосуються суб'єктивної сторони кримінального правопорушення. В наслідок цього нами було розглянуто та досліджено місце наміру серед усіх елементів суб'єктивної сторони. Шляхом аналізу виявлено, що на сьогодні складною і невирішеною залишається проблема співвідношення понять намір та умисел. Після дослідження психологічних властивостей та герменевтичного значення обох термінів було зроблено висновок про те, що умисел може виступати різновидом наміру, одним із його видів, охоплюючи собою лише деякі із ознак та особливостей наміру. На підставі того, що сьогодні постала потреба створення нового КК України нами було висвітлено власну позицію щодо обѓрунтованості вживання у ньому поняття «намір». Керуючись тим, що на сьогодні умислу відводиться важливе місце серед обов'язкової ознаки суб'єктивної сторони та його чітке законодавче закріплення, усталене місце у кримінальному праві, нами було запропоновано замінити поняття «намір» на «умисел», що дозволить спростити теоретичну базу нового КК України та наблизити її до більш лаконічної, стислої та чітко викладеної системи.
\end{abstract}

Ключові слова: намір, умисел, суб'єктивна сторона кримінального правопорушення, фракультативні ознаки, форми вини.

Myslyvyi Volodymyr, Ohievich Sofiia National Technical University of Ukraine «Igor Sikorsky Kyiv Polytechnic Institute»

\section{CRIMINAL INTENTION AS A CATEGORY IN THE CRIMINAL LAW OF UKRAINE}

Summary. This article is devoted to the study of the concept of "intention" given the need for its use in the new version of the Criminal Code of Ukraine. In the course of the work a number of problems and unresolved issues related to the research topic were identified. In particular, it was found that in the repeated use of the term "intention" in the Code, its interpretation is not provided by the legislator. Based on this, we analyzed the meaning of the concept of "intention" through philological research: clarified the peculiarities of the interpretation of the term and its etymological meaning. Since the intention is directly formed in the human mind and depends on his expression of will, it became necessary to consider the category of "intention" on the basis of psychological work and research. Thus, "intention" was attributed to one of the stages of a complex act of will and defined as a mandatory element of any form of human activity, the occurrence of which may be sudden and due to life circumstances. In the course of the work it was noted that the complexity of the definition and legislative consolidation of the term "intention" is due to its direct relation to the psychological processes of human life. However, the importance of this term is explained by the presence of a number of issues, in particular concerning the subjective side of the criminal offense. As a result, we have considered and explored the place of intent among all elements of the subjective side. Through analysis, it was found that today the problem of the relationship between the concepts of intention and design remains complex and unresolved. After studying the psychological properties and hermeneutic meaning of both terms, it was concluded that design can be a kind of intention, one of its types, covering only some of the signs and features of intention. Based on the fact that today there is a need to create a new Criminal Code of Ukraine, we have highlighted our own position on the validity of the use of the concept of "design". Guided by the fact that today design is given an important place among the obligatory feature of the subjective side and its clear legislative enshrinement, a well-established place in criminal law, we proposed to replace the concept of "intention" with "design", which will simplify the theoretical basis of the new Of the Criminal Code of Ukraine and bring it closer to a more concise and clearly defined system.

Keywords: intent, design, subjective side of a criminal offense, optional features, forms of guilt.

$\Pi^{2}$ остановка проблеми. Аналіз нинішнього кримінального законодавства України свідчить про використання поняття «намір» у таких статтях Кримінального кодексу України (далі - КК України) як ч. 2 ст. 32 , ч. 1 ст. 68 , ч. 1 ст. 96-10, але чіткого тлумачення цього терміну законодавцем не надаеться. Крім цього, зі сторони науковців розгляд даного поняття зустрічаеться вкрай рідко, що досить ускладнюе процес дослідження наміру як кримінальної 
категорії. При вивченні праць вчених у сорері кримінального права, домінуючою є позиція про співвідношення понять “намір» та "умисел» як синонімічних, проте, чітке обгрунтування та закріплення такого підходу у кримінальному праві також відсутне. Зважаючи на численну кількість невирішених та малодосліджених питань, а також беручи до уваги те, що на сьогодні відбувається активна робота зі створення нового КК України, доцільним буде звернути увагу на дану проблему та дослідити ї у контексті не лише кримінології, а й фрілології та психології.

Аналіз останніх досліджень і публікацій. На сьогодні існуе досить обмежена кількість праць, присвячених розгляду поняття "наміру» як злочинної категорії, зокрема до них можна віднести публікації таких авторів: Р.В. Вереша, В.В. Бурдін, Н.В. Маслак, В.С. Тарасенко, Л.М. Федорак.

Виділення не вирішених раніше частин загальної проблеми. У контексті теми роботи невирішеними $є$ питання тлумачення терміну "намір», визначення його місця серед елементів суб'єктивної сторони та його співвідношення 3 терміном «умисел».

Мета статті. Головною метою ціеї роботи є здійснення аналізу застосування терміну "намір» у кримінальному праві, дослідження його фрілологічного та етимологічного значення, розгляд даного поняття у психологічному контексті, а також встановлення ролі та місця наміру в науці кримінального права й обгрунтування міри необхідності його використання у новому КК України.

Виклад основного матеріалу. Поняття «намір» вживається законодавцем у таких статтях КК України, як ч. 2 ст. 32 «Про повторність кримінальних правопорушень», у якій йде мова про відсутність повторюваності за умови, що тотожні діяння об'єднані єдиним кримінально протиправним наміром. У ч. 1 ст. 68 «Про призначення покарання за незакінчене кримінальне правопорушення та за кримінальне правопорушення, вчинене у співучасті» як і в ч. 1 ст. 96-10 щодо загальних правил застосування до юридичних осіб заходів кримінально-правового характеру зазначається те, що суд уповноважений, керуючись відповідними положеннями КК України, враховувати ступінь здійснення кримінально протиправного наміру [1]. Проте, незважаючи на неодноразове використання законодавцем у КК України поняття «намір», його визначення або тлумачення не надається. У даному випадку цілком доречно буде погодитися із думкою Вереша Р.В. про те, що «кожна категорія та поняття, що вживаються в КК України, повинні мати максимально чіткий і зрозумілий зміст», чим і зумовлюеться необхідність визначити місце та значення наміру у кримінальному праві [2, с. 209].

У зв'язку 3 цим та 3 метою детального аналізу і якомога глибшого розкриття змісту даного поняття доцільно дослідити його фрілологічне значення. Виходячи з цьог, відзначимо, що в академічному словнику української мови тлумачення терміну «намір» подається як задум, бажання зробити що-небудь. Відповідно «задум» розуміеться як задуманий план дій, а «бажання» - як прагнення, потяг до здійснення чогонебудь; хотіння чи висловлювана особою думка про бажаність здійснення чого-небудь [3]. 3 точки зору етимології, виникнення поняття «намір» пов'язуеться із такою більш ранньої категорією, як «замір» або «міряти (у значенні - «цілити»). В етимологічному словнику української мови виникнення поняття «намір» пояснюеться як процес пов'язаний із «видозміною раніше більш поширеної форми замір під впливом російського «намерение» [4].

Зважаючи на те, що намір безпосередньо формується у свідомості людини та залежить від їі волевиявлення, дослідження поставленого питання потребуе його вивчення у психологічному контексті. Загальне визначення поняття "намір» у психологічній науці сформовано як рішення людини виконати певну дію 3 метою настання бажаних наслідків. Аналіз людиною поставленої мети та завдань виступає підгрунтям для виникнення намірів [5]. У психології «намір» розглядається взаємопов'язано з поняттям волі та вольових дій, які проявляються у простій та складній формі. Основними елементами, що ускладнюють процес формування волі є врахування особою наслідків, усвідомлення мотивів та прийняття рішень. Таким чином, у психології поняття "намір» є одним із етапів складного вольового акту, який виникає з моменту спонукання до його здійснення, супроводжуеться усвідомленням особою мети своїх дій, уявленням необхідних засобів для її досягнення, виникненням наміру здійснити певну дію та закінчуеться прийняттям рішення і його виконанням [6].

На думку 3. Фрейда, намір виступає своєрідним імпульсом до виконання певної дії, яка вже була схвалена, але виконання якої особа перенесла на певний момент [7]. Водночас Е. Анськомб вважає, що намір є класичним джерелом думки, яка виникає у момент переходу від переконання та бажання [8]. Виходячи з цього, можна узагальнити, що намір є обов'язковим елементом будь-якої форми людської діяльності, виникнення якого може бути раптовим та зумовлюеться життевими обставинами.

На сьогодні науковцями у галузі психології розроблені різні варіанти класифікацій намірів, одним із яких є розподіл за фрункціональним призначенням. Згідно з ним, виділяють категорії намірів, які спрямовані на задоволення потреб життедіяльності організму людини та на емоційне забарвлення психологічного стану людини. Не менш важливим є рівень усвідомлення намірів, залежно від якого наміри поділяють на: 1) усвідомлювані - наміри, про які людина готова говорити, зазначаючи причину їх здійснення; 2) підсвідомі - наміри, що виникають як результат програми, яку отримала людина в поточному житті, а також як результат подій, що відбувались в її житті [9, с. 4].

Отже, у психології намір е суб'єктивним психологічним феноменом, який передбачає dpopмування у свідомості динамічного стану напруження з метою покладання цілей і перетворення останніх у план дій, що у майбутньому реалізується у реальній діяльності завдяки можливому набору засобів реалізації конкретної мети для кожної конкретної людини [9, с. 10].

При використання результатів психологічних досліджень у кримінальному праві, варто пого- 
дитися із думкою Федорак Л. М. про те, що кримінально-правові поняття різних аспектів, зокрема і суб'єктивної сторони, зазвичай є лише інтегрованим юридичним відображенням різних психологічних реалій, що часто можуть бути неточними. Законодавець, як правило, спрощуе складну психічну діяльність людини, через об'єктивну неможливість вичерпно втілити будь-які реалії в конкретних поняттях і термінах кримінального права. Крім цього, кримінальне право вирішуе суто юридичні завдання, які не беруть до уваги глибинні психологічні взаємозв'язки. У наслідок цього часто виникають дискусійні і невирішені питання, зокрема і неможливість чітко визначити зміст поняття «злочинний намір» та закріпити його на законодавчому рівні [10, с. 45].

При розгляді поняття «намір» у кримінальному праві, варто наголосити на тому, що за загальним правилом наміри людини не можуть створювати склад правопорушення, оскільки вони насамперед повинні бути втілені у фрормі суспільно небезпечного діяння (дії чи бездіяльності), що визначаеться ст. 11 КК України [1]. Таким чином, в основі сучасного кримінального права лежить принцип: «cogitations poenam nemo patitur» («ніхто не підлягає покаранню за свої думки»). Проте, у кримінальному праві поняття "намір» все ж таки відіграе досить важливу роль при розгляді ряду питань, зокрема що стосуються суб'єктивної сторони кримінального правопорушення. Так, Борисов В. I. і Ломако В. А. пропонують визначення суб'єктивної сторони, згідно з яким це «внутрішня сторона злочину, тобто психічна діяльність особи, що відображає ставлення її свідомості і волі до суспільно небезпечного діяння, яке вона вчиняе, i до його наслідків» [11, с. 152]. Основними поняттями, які характеризують суб'єктивну сторону, є вина, мотив та мета вчинення кримінально протиправного діяння. На відміну від вини, яка $є$ обов'язковою ознакою будь-якого складу кримінального правопорушення, мета та мотив виступають здебільшого фракультативними ознаками, за умови, що вони не вказані в диспозиції закону як обов'язкові ознаки конкретного діяння. У свою чергу, мета у кримінальному праві - це бажання особи досягнути певних шкідливих наслідків, а мотив є спонуканням до вчинення діяння.

Крім перерахованих елементів до цього переліку дедалі частіше науковці відносять поняття емоційного стану у формі афректу - стану сильного душевного хвилювання. Така тенденція, на нашу думку, є обгрунтованою 3 погляду на те, що законодавець використовуе дану категорію у ряді кримінально-правових норм, зокрема ч. 4 ст. 36 , ч. 3 ст. 39 , ст. 116 , ст. 123 КК України тощо [1]. Емоційний стан відображає переживання та відчуття, які супроводжують особу під час готування та безпосереднього вчинення самого кримінального правопорушення. Варто зауважити, що Дудоров О. О. і Хавронюк М. I. розглядають емоційний стан у двох аспектах: як чинник, що впливає на здатність винного усвідомлювати характер своїх дій і керувати ними (стосуеться категорії осудності) та як такий, що не впливає на зазначені дії [10, с. 185]. Для визначення суб'єктивної сторони мають значення саме ті емощії, які можуть дати відповідь на пи- тання про фрактори, які спонукали винного вчинити кримінальне правопорушення.

Визначення усіх елементів суб'єктивної сторони кримінального правопорушення має важливе значення у кримінальному праві, оскільки впливае на кваліфікацію злочину, визначення та обгрунтування ступеня небезпечності вчиненого протиправного діяння, а також дозволяе індивідуалізувати покарання відповідно до психологічного стану суб'єкта.

Таким чином, важливість визначення змісту суб'єктивної сторони безпосередньо посилює потребу встановити місце наміру серед понятійних категорій даної ланки. 3 цією метою найдоцільніше буде розглянути саме обов'язковий елемент суб'єктивної сторони - вину. Згідно зі ст. 23 КК України, виною є психічне ставлення особи до вчинюваної дії чи бездіяльності та їі наслідків [1]. Зміст вини як елемента суб'єктивної сторони кримінального правопорушення містять інтелектуальні та вольові ознаки. Інтелектуальний аспект відображається в усвідомленні особою своїх дій чи бездіяльності, а вольовий - в наявності у неї бажання вчинити певну дію чи бездіяльність. У ст. 24 і ст. 25 КК України вказані дві форми вини - умисел та необережність, які в свою чергу поділяються на різновиди: умисел на прямий і непрямий, а необережність - на самовпевненість і недбалість [1].

При дослідженні питання злочинного наміру у кримінальному праві залишається складною і невирішеною проблема співвідношення понять намір та умисел, оскільки у навчальній літературі із кримінального права досить часто можна зустріти ототожнення цих термінів, проте, чітке обгрунтування такої позиції у кримінальному праві на сьогодні практично відсутне. У свою чергу «Академічний словник з української мови» при тлумаченні умислу надає такий його варіант: «це заздалегідь обдуманий план, налір (курсив наш - C.O.), переважно таємний, вартий осуду» [3]. Натомість, відповідно до ч. 2 ст. 24 КК України злочин визнається вчиненим умисно, коли особа, яка його вчинила, усвідомлювала суспільно небезпечний характер своєї дії або бездіяльності, передбачала їі суспільно небезпечні наслідки і бажала їх або свідомо припускала настання цих наслідків [1]. Отже, вказана норма терміну «намір» взагалі не містить.

Якщо порівняти кримінально-правові ознаки умислу із герменевтичним значенням та психологічними властивостями поняття "наміру», дослідженими в цій статті, то можна дійти до висновку, що повністю ототожнювати ці поняття не варто, оскільки, по-перше, намір за своїм лексичним значенням $є$ ширшим поняттям та охоплює собою умисел. По-друге, намір, згідно із психологічними дослідженнями, класифікуеться на усвідомлюваний та підсвідомий, на відміну від умислу, інтелектуальний момент якого уже передбачає в якості головної ознаки усвідомлення особою своїх дій чи бездіяльності. Виходячи з цих положень, доцільно зауважити, що умисел може виступати різновидом наміру, одним із його видів, охоплюючи собою лише деякі із ознак та особливостей наміру. При цьому умисел, як характеризуюча ознака протиправного діяння, посідае важливе місце у кримінальному праві, оскільки, 
як стверджує Вереша Р. В., умисні злочини несуть підвищену суспільну небезпечність, оскільки умисними суспільно небезпечними діяннями свідомо заподіюється шкода об'єкту кримінально-правової охорони. До того ж, умисний злочин характеризуеться тим, що передбачає високу вірогідність настання бажаних (або таких, що свідомо припускаються) суспільно небезпечних наслідків, оскільки свідоме ставлення до своїх діянь спрямовуе останні на досягнення злочинного результату [2, с. 207].

Зважаючинате, щосьогодніпосталапотреба створення нового КК України, над яким активно працюе робоча група з питань розвитку кримінального права, основною метою діяльності якої є вдосконалення правової системи України та задоволення потреб демократичного суспільсва, вбачаємо за доцільне на основі проведеного аналізу висвітлити власну позицію щодо обюрунтованості вживання у новому кримінальному кодексі поняття "намір», оскільки даний термін неодноразово зустрічається у проекті нового КК України, зокрема у ст. 2.3.8. Фактична помилка, ст. 2.5.3. Провокація злочину ст. 2.6.4. Одиничний злочин та його види [13]. Оскільки в науці кримінального права поняття намір та умисел неодноразово співвідносять між собою як синоніми, вважаємо, що з метою уникнення ряду невирішених питань та спрощення теоретичної основи нового КК України цілком обгрунтовано буде замінити поняття «намір» на «умисел». Ми погоджуемося із думкою відомого вченого Трайніна Н. С. про те, що репресивна діяльність держави може мати справу 3 діяннями людей, а не з їх бажаннями та задумами [14], оскільки дійсно між помислами людини та ії реальними діями часто існуе величезна прірва, яка у процесі кримінального судочинства повинна заповнюватися не довільними судженнями про існування злочинної волі, а конкретними злочинними діями, що підтверджують їі рішучість реалізащії. Проте, варто взяти до уваги, що в науці кримінального права, у чинному КК України і в проекті нового КК України умислу відводиться важливе місце серед обов'язкової ознаки суб'єктивної сторони вини. Зважаючи на чітке законодавче закріплення умислу, його усталене місце у кримінальному праві, зникає потреба одночасного вживання поняття «намір», чим і обгрунтовуеться пропозиція заміни даного поняття на «умисел».

Висновки і пропозиції. На основі здійсненого аналізу можна зробити висновок про те, що намір на сьогодні $є$ законодавчо невизначеним терміном, не зважаючи на своє застосування як у чинному КК України, так і в проекті нового КК України. В українській мові визначення намір подається як задум, бажання зробити щонебудь. Натомість результати психологічного дослідження «наміру» дають підстави визначити його, як суб'єктивний психологічний феномен, який передбачає формування у свідомості динамічного стану напруження з метою покладання цілей і перетворення останніх у план дій, що у майбутньому реалізується у реальній діяльності. Визначаючи місце наміру серед кримінальних категорій, найбільш обгрунтованим є розгляд даного поняття у контексті суб'єктивної сторони кримінального правопорушення. Під час аналізу численних праць у сфері кримінального права, домінуючою є позиція про співвідношення понять «намір» та «умисел» як синонімічних. Даний підхід дозволяе віднести намір до такої обов'язкової ознаки суб'єктивної сторони як вина. На підставі проведеного порівняння даних термінів постало питання про доцільність одночасного вживання обох визначень. Беручи до уваги те, що в науці кримінального права, у чинному КК України і в проекті нового КК України умислу відводиться важливе місце серед обов'язкової ознаки суб'єктивної сторони - вини та зважаючи на чітке законодавче закріплення умислу, його усталене місце у кримінальному праві, більш обгрунтованим $є$ надання переваги даному терміну. Крім того, застосування у КК України поняття "намір» є підставою для виникнення суперечностей та ряду невирішених питань, які потребують вивчення та глибокого дослідження. У свою чергу, висловлена позищія щодо заміни поняття «намір» на "умисел» дозволить спростити теоретичну базу нового КК України та наблизити її до більш лаконічної, стислої та чітко викладеної системи.

\section{Список літератури:}

1. Кримінальний кодекс України : Закон України від 5 квітня 2001 р. № 2341-III. URL: https://zakon.rada.gov.ua/ laws/show/2341-14\#Text (дата звернення: 12.11.2020).

2. Вереша Р.В. Проблеми суб'єктивної сторони складу злочину : дис. ... д-ра юрид. наук. Київ, 2017.583 с.

3. Словник української мови. Академічний тлумачний словник (1970-1980) : в 11 томах. URL: http://sum.in.ua/ (дата звернення: 12.11.2020).

4. Етимологічний словник української мови : у 7 т. Т. 4: Н-П І Уклад.: Р.В. Болдирев та ін.; Ред. тому: В.Т. Коломіець, В.Г. Скляренко. Київ : Наукова думка, 2003. 657 с.

5. Термінологічний словник. Основи психології та педагогіки : лабораторний практикум : веб-сайт. URL: https://web.posibnyky.vntu.edu.ua/icgn/11prishak_osnovy_psiholog_pedagogiki_labpraktik/slovn.html (дата звернення: 12.11.2020).

6. Поняття волі і вольової дії. Етапи формування складного вольового акту : веб-сайт. URL: http://library.nlu.edu.ua/ POLN_TEXT/KNIGI/1_DISKI/UR_PSIX/html/11.htm (дата звернення: 09.11.2020).

7. Фрейд З. Забывание иностранных слов. Хрестоматия по общей психологии. Психология памяти / Под ред. Ю.Б. Гиппенрейтер, В.Я. Романова. Москва : Изд-во МГУ, 1980. С. 104-119.

8. Anscombe, G.E.M. Intention / G.E.M. Anscombe. Ithaca : Cornell University Press, 1957. Pp. 32, 48.

9. Волинець Н.В. Філософсько-психологічні аспекти феномену наміру. Вісник Національної акаделї̈ Державноі прикордонної служби України. 2012. Вип. 1. URL: http://nbuv.gov.ua/UJRN/Vnadps_2012_1_27 (дата звернення: 12.11.2020).

10. Федорак Л. М. Злочинний намір у кримінальному праві України. Вісник Верховного Суду Украӥни. 2015. № 11. C. 44-48.

11. Кримінальне право України: Загальна частина : підручник / [Ю.В. Баулін, В.І. Борисов, В.І. Тютюгін та ін.]; за ред. профр. В.В. Сташиса, В.Я. Тація. 4-те вид., переробл. і допов. Харків : Право, 2010.456 с. URL: http://library.nlu.edu.ua/POLN_TEXT/KNIGI-2010/UgolovPravoZag.pdf (дата звернення: 12.11.2020). 
12. Дудоров О.О., Хавронюк М.I. Кримінальне право : Навчальний посібник / За заг. ред. М.I. Хавронюка. Київ : Ваіте, 2014. 944 с.

13. Новий Кримінальний Кодекс : веб-сайт. URL: https://newcriminalcode.org.ua/criminal-code (дата звернення: 18.11.2020)

14. Трайнин Н.С. Русское уголовное право. Лекции. Часть общая. В 2 т. Т. 1. Москва : Наука, 1994. 380 с.

\section{References:}

1. Kryminalnyi kodeks Ukrainy [Criminal codex of Ukraine]: Zakon Ukrainy vid 5 kvitnia 2001 r. № 2341 -III. URL: https://zakon.rada.gov.ua/laws/show/2341-14\#Text (accessed 12 November 2020).

2. Veresha R.V. (2017) Problemy subiektyvnoi storony skladu zlochynu [Problems of the subjective side of the crime]: dys. ... d-ra yuryd. nauk. Kyiv, pp. 583.

3. Slovnyk ukrainskoi movy. Akademichnyi tlumachnyi slovnyk [Dictionary of the Ukrainian language. Academic explanatory dictionary] (1970-1980): v 11 tomakh. URL: http://sum.in.ua/ (accessed 12 November 2020).

4. Etymolohichnyi slovnyk ukrainskoi movy [Etymological dictionary of the Ukrainian language]: u 7 t. T. $4:$ N-P I Uklad.: R.V. Boldyriev ta in.; Red. tomu: V.T. Kolomiiets, V.H. Skliarenko. Kyiv: Naukova dumka, 2003, p. 657.

5. Terminolohichnyi slovnyk. Osnovy psykholohii ta pedahohiky: laboratornyi praktykum [Terminological dictionary. Fundamentals of psychology and pedagogy: laboratory workshop]: veb-sait. URL: https://web.posibnyky.vntu.edu.ua/ icgn/11prishak_osnovy_psiholog_pedagogiki_labpraktik/slovn.html (accessed 12 November 2020).

6. Poniattia voli i volovoi dii. Etapy formuvannia skladnoho volovoho aktu [The concept of will and volitional action. Stages of formation of a complex act of will]: veb-sait. URL: http://library.nlu.edu.ua/POLN_TEXT/KNIGI/1_ DISKI/UR_PSIX/html/11.htm (accessed 09 November 2020).

7. Freid Z. (1980) Zabyvanye ynostrannykh slov. Khrestomatyia po obshchei psykholohyy. Psykholohyia pamiaty [Forgetting foreign words. A textbook on general psychology. Psychology of memory] / Pod red. Yu.B. Hyppenreiter, V.Ya. Romanova. Moscow: Yzd-vo MHU, pp. 104-119.

8. Anscombe, G.E.M. Intention (1957) / G.E.M. Anscombe. Ithaca: Cornell University Press, pp. 32, 48.

9. Volynets N.V. (2012) Filosofsko-psykholohichni aspekty fenomenu namiru [Philosophical and psychological aspects of the phenomenon of intention]. Visnyk Natsionalnoi akademii Derzhavnoi prykordonnoi sluzhby Ukrainy, vol. 1. URL: http://nbuv.gov.ua/UJRN/Vnadps_2012_1_27 (accessed 12 November 2020).

10. Fedorak L.M. (2015) Zlochynnyi namir u kryminalnomu pravi Ukrainy [Criminal intent in the criminal law of Ukraine]. Visnyk Verkhovnoho Sudu Ukrainy, no. 11, pp. 44-48.

11. Kryminalne pravo Ukrainy: Zahalna chastyna: pidruchnyk (2010) [Criminal law of Ukraine: General part: textbook] / [Iu.V. Baulin, V.I. Borysov, V.I. Tiutiuhin ta in.]; za red. prof. V.V. Stashysa, V.Ya. Tatsiia. 4-te vyd., pererobl. i dopov. Kharkiv: Pravo, pp. 456. URL: http://library.nlu.edu.ua/POLN_TEXT/KNIGI-2010/ UgolovPravoZag.pdf (accessed 12 November 2020).

12. Dudorov O.O., Khavroniuk M.I. (2014) Kryminalne pravo: Navchalnyi posibnyk [Criminal Law: A Textbook] / Za zah. red. M.I. Khavroniuka. Kyiv: Vaite, pp. 944.

13. Novyi Kryminalnyi Kodeks [New Criminal Code]: veb-sait. URL: https://newcriminalcode.org.ua/criminal-code (accessed 18 November 2020).

14. Trainyn N.S. (1994) Russkoe uholovnoe pravo. Lektsyy. Chast obshchaia [Russian criminal law. Lectures. The part is common]: v 2 t. T. 1. Moscow: Nauka, p. 380. 